p-ISSN 1693-1246

e-ISSN 2355-3812

January 2017
Jurnal Pendidikan Fisika Indonesia 13 (1) (2017) 9-18

DOI: $10.15294 / j p f i . v 13 i 1.8982$ http://journal.unnes.ac.id/njul/index.php/jpfi

\title{
ONLINE-COURSE DEVELOPMENT VIA DISCUSSION-FORUM ON THE STUDENTS OF PHYSIC EDUCATION UNIVERSITAS NEGERI SEMARANG
}

\author{
I. Sudarwati, S. Khanafiyah, Sugiyanto* \\ Jurusan Fisika, Fakultas Matematika dan Ilmu Pengetahuan Alam, \\ Universitas Negeri Semarang, Indonesia
}

Received: : 2 July 2016. Accepted: 20 September 2016. Published: January 2017

\begin{abstract}
Students of Physic Education of Universitas Negeri Semarang often find some difficulties to understand the material. During difficult times, students usually find references on the internet,ask a friend who already understand, or ask a senior friend. Mostly students have a device that can be used to access the internet. Online-course via discussion-forum can be used as a discussion facility when they find difficulties to understand. Online-course via discussion-forum developed with ADDIE development models that includes the stages of analysis, design, development, implementation, and evaluation. Online-course discussion forum contains the list of courses that can be accessed by students via internet through the website discussion.belajarfisika.web.id. Feasibility of online course discussion forum was measured through assessment sheets of feasibility test from validators and questionnaire responses from students. The results of the feasibility test from the validator and student responses indicate that criteria are eligible. Results of the questionnaire about students' perceptions of learning through online course discussion forum show that Physic Education Students of Universitas Negeri Semarang have good perceptions of learning through online-course via discussion-forums.
\end{abstract}

\begin{abstract}
ABSTRAK
Mahasiswa Pendidikan Fisika UNNES sering merasa kesulitan memahami materi perkuliahan. Saat mengalami kesulitan, mahasiswa biasanya mencari referensi di internet, bertanya pada teman yang sudah paham, atau bertanya pada kakak angkatan. Mahasiswa memiliki perangkat yang dapat digunakan untuk mengakses internet. Forum diskusi kuliah online dapat digunakan sebagai fasilitas diskusi mahasiswa ketika mengalami kesulitan memahami materi. Forum diskusi kuliah online dikembangkan dengan model pengembangan ADDIE yang meliputi tahap analisis masalah, desain, pengembangan, penerapan, dan evaluasi. Forum diskusi kuliah online berisi daftar mata kuliah yang dapat diakses oleh mahasiswa dengan internet melalui laman diskusi.belajarfisika.web.id. Kelayakan forum diskusi kuliah online diukur melalui lembar penilaian uji kelayakan dari validator dan angket tanggapan dari mahasiswa. Hasil uji kelayakan dari validator dan tanggapan mahasiswa menunjukkan bahwa forum diskusi kuliah online termasuk dalam kriteria layak. Hasil angket persepsi mahasiswa tentang belajar melalui forum diskusi kuliah online menunjukkan bahwa mahasiswa pendidikan fisika UNNES memiliki persepsi yang baik tentang belajar melalui forum diskusi kuliah online.
\end{abstract}

(C 2017 Jurusan Fisika FMIPA UNNES Semarang

Keywords: online-discussion; discussion-forum; perception

\section{INTRODUCTION}

Interviews with some students indicated that they felt that the time for face-to-face lessons was inadequate for the delivery of course

*Correspondence Address:

D7 Building 2nd Floor Sekaran Gunung Pati Semarang 50229 E-mail: idaa.sudarwati@gmail.com materials. Students found it difficult to understand the lecture material.

When experiencing difficulties, students usually look for references from the internet, ask friends who already understand, or ask senior friends. Therefore, it is necessary to have a discussion forum that can accommodate the 
questions of students who have difficulties related to the lecture material that is submitted to other students so that other students who have mastered can help provide the settlement.

Constructivism learning theory states that students should be active in shaping their knowledge (Baharuddin \& Wahyuni, 2008). Therefore, the learning process is expected to encourage students to actively construct their knowledge, not just receiving information. One of the ways for active knowledge-building can be done by interacting with other students.

Discussion is one example of the application of constructivism learning theory in learning (Schunk, 2012). According to Hasibuan \& Moedjiono's theory (2006), the discussion is a visual process two or more individuals who interact verbally and with each other face to face about the goals or objectives that have been specified by way of exchange of information, maintains opinions, or problem solving. Discussion can encourage interaction between students as well as between students and teachers. With this interaction, students will get an opportunity to express their opinions and hear the opinions of friends so as to know various points of view to solve the problem.

The definition of Hasibuan \& Moedjiono contains face-to-face phrases so it can be said to be a traditional discussion or class discussion. Traditional discussion has several disadvantages. The problems of the traditional discussion of which requires participants to gather in one place and time limited discussion (Meyer, 2003), especially if the discussion carried out when the lecture. The weakness of the traditional discussion can be solved by online-discussion. The advantages of onlinediscussion are giving the freedom of time and place to start or respond to a discussion, giving time to reflect and think, and discussion can be archived (Th ompson, 2005 and Meyer, 2003).

The online-course via discussion-forum accessed via the Internet can facilitate the interaction between students and make students active in their learning through online-discussion. Online-course via discussion-forum is one form of the website. Aladwani \& Palvia (2001) stated that the quality of the website includes technical aspects, content and design. Levine (2007) provides conditions that can be used as a guide to keep online discussions can be used effectively. Ten of these conditions namely: (1) create an atmosphere that is condusif for learning, (2) set the rules and provide instruction on opening, (3) convey meaningfull questions and issues, (4) focus on three highest levels of the cognitive domain, (5) guide continuity of discussion, (6) give advocates thinking, (7) appreciate individuality without isulation, (8) being sensitive to nonparticipants, (9) encourage participation, and (10) summarize the main idea.

Interaction facility of online-course discussion forum allowing students to interact in a discussion without limitation of time and place and give it time to think before giving opinion. The archive facility allows students to review the content of the discussion. Interaction and archive facilites contained in a online-course via discussion-forum can help students in their learning.

The number of Internet users continues to increase. Based on the data of Indonesia Internet User Profiles 2014, the number of internet users in Indonesia as much as 88.1 million people until the end of 2014 from 252.4 million people of the population. $18 \%$ of the total internet users are students. One use of the Internet is for online forums / online communities $4.3 \%$ (APJII, 2015).

The results of early research in 45 students of Physical Education at UNNES (Universitas Negeri Semarang) provide information that they have a device that can be used to access the Internet. Currently, Physic Education students of UNNES utilize social media to share information about activities or events organized by student organizations. Not yet available facilities devoted to the discussion of course materials for students of Physics Education of UNNES. Mazzolini's research (2002) states that on the use of online discussion-forum on Astronomy program showed that students feel comfortable because it can contribute to the online discussion-forum.

Based on the data above, it is nessesary to develop an online discussion forum for students of Physic Education at UNNES.

This research aims to develop an online-course via discussion-forum, determine the feasibility of online-course via discussionforum, and know the perception of Physic Education students about learning through onlinecourse via discussion-forums.

\section{METHOD}

This study was conducted by research and development. Methods used to produce a particular product, and test the effectiveness of the product (Sugiyono, 2013). The product resulting from this study is a online-course via 
discussion-forum for students of Physic Education.

The study was conducted in the Department of Physics at UNNES in the semester of the academic year 2016/2017. The subject of this study is online-course via discussion-forum of Physic Education students at UNNES. The object of the study examined the feasibility of online-course via discussion-forum of Physic Education Students at UNNES, students' responses and students' perceptions about learning through online-course via discussionforum. The respondents were divided into two groups, namely the validator group and the user group. Respondents were selected using purposive system. Purposive system is a system to determine the respondents with certain consideration (Sugiyono, 2010). In this study the validator group is lecturer of the Department of Physics at UNNES. Validator is chosen based on scientific background and education and profession. The selected user group is student of Physic Education has taken advantage of online-course via discussion-forum of the three forces. The user group is selected only from UNNES because in this study the user group will be given a written questionnaires. Questionnaires given are questionnaires which contain students' responses and students' perceptions about learning through online-course via discussion-forum. In the students' perceptions questionnaire about learning through online-course via discussion-forum, there are aspects to facilitate the study of physics.

The development in this research uses the modified ADDIE model from Arkün \& Akkoyunlu (2008). ADDIE includes phase analysis (analysis of the problem), design (design), development (development), implementation (implementation), and evaluation (evaluation).

This research uses two methods of data collection namely assessment sheet and questionnaire. Assessment sheet is used to assess the feasibility of an online-course via discussion-forum. The assessment sheet is given to the validator. The assessment sheet of onlinecourse via discussion-forum covering technical aspects, content and design. Election aspects of the assessment based on the criteria developed by Aladwani website \& Palvia (2001).

Questionnaire is a technique of data collection is done by giving a set of questions or a written statement to the respondent to be answered (Sugiyono, 2013). Questionnaire in this research use likert scale 1-5. Questionnaire is used to determine the response of students to online-course via discussion-forum and students' perceptions about learning through online-course via discussion-forum. Students' responses questionnaire covering technical aspects, content and design of online-course via discussion-forum. Questionnaire perception includes aspects of ease of use, level of interactivity, comfort in physics learning, ease in physics learning, and advanced use.

Analysis was performed on the data obtained from the assessment of the feasibility online-course via discussion-forum validator, the response of students to online-course via discussion-forum, as well as the perceptions of students about learning through online-course via discussion-forum. The level of product feasibility, students' responses and students' perceptions is calculated with percentage. According to Sudijono's theory (2003), to obtain a percentage of a value can be calculated using equation (1).

$$
P=\frac{F}{N} \times 100 \%
$$

Information:

$P$ : Percentage rate (\%)

$F$ : The amount sought score percentage

$N$ : Total score

Results obtained from calculation is converted into qualitative criteria. Criteria for eligibility levels and responses online-course via discussion-forum:

$84 \%<$ value $\leq 100 \%=$ Very Eligible

$68 \%<$ value $\leq 84 \%$ = Eligible

$52 \%<$ value $\leq 68 \%$ = Enough

$36 \%<$ value $\leq 52 \%=$ Less Eligible

$20 \% \leq$ value $\leq 36 \%=$ Not Eligible

Criteria for students' perceptions of learning in online-course via discussion-forum:

$84 \%<$ value $\leq 100 \%=$ Very Good

$68 \%<$ value $\leq 84 \%=$ Good

$52 \%<$ value $\leq 68 \%=$ Good Enough

$36 \%<$ value $\leq 52 \%=$ Less Good

$20 \% \leq$ value $\leq 36 \%=$ Not Good

(Directorate Technical High School, 2010)

\section{RESULTS AND DISCUSSION}

online-course via discussion-forum was developed by using ADDIE development model of Arkün \& Akkoyunlu (2008) which is modified. ADDIE Model includes phase analysis (analysis of the problem), design (design), development (development), implementation (implementation), and evaluation (evaluation). 


\section{Problem analysis}

Analysis in this research is done to know the problem and potency. Therefore, it is conducted interviews and questionnaires to students of Physics Education. Interviews showed the problems experienced by students of Physical Education that is difficult to understand the lecture material. The results of the questionnaire administration demonstrate the potential that is possible to access the facility via the Internet. From problems and potential points, the researchers developed the online-course via discussion-forum. online-course via discussion-forum is expected to be used by students of Physic Education at UNNES (Semarang State University) for discussions related to the lecture material so that it can overcome the difficulties in understanding the lecture material. online-course via discussion-forum developed can be accessed through a web browser with a specific domain address. This forum contains a list of courses that can be used for discussion in the appropriate courses.

The development of online-course via discussion-forum using the CMS forum phpBB. PhpBB modified to be suitable for use as a online course discussion forum. For this development, the software used is

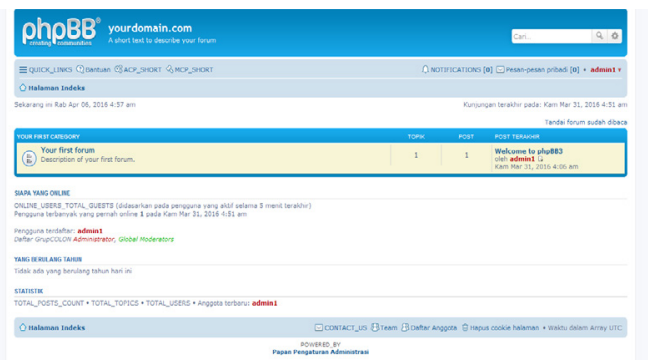

Figure 1. Results of phpBB installation.

- $\quad$ PhpBB 3.1.8 Ascraeus,

- $\quad$ Notepad ++,

- XAMPP,

- web browsers,

- Domain, and

- web hosting.

- PhpBB 3.1.8 can be downloaded in the yard https: //www.phpbb.com/downloads/.

- $\quad$ The system needed to use phpBB 3.1.8 is as follows.

- Web server that supports PHP.

- $\quad$ PHP version 5.3.3 or above.

The SQL database system, for MySQL version 3.23 or above.

\section{Designing}

After the problem analysis is complete, the product design begins. Product design starts with phpBB installation. The initial installation results in Indonesian are shown in Figure 1.

\section{Counters Number User Login}

It is important for a system to document the activities that the user of the system performs. One of them is to find out how often the user is logged into the system. The counter number of user login is placed on the file function.php file includes folder and inserted into the function login_box in logic of login_success. Earlier, also added a column in the table user_login_count users. Flowchart user login number counter is shown in Figure 2.

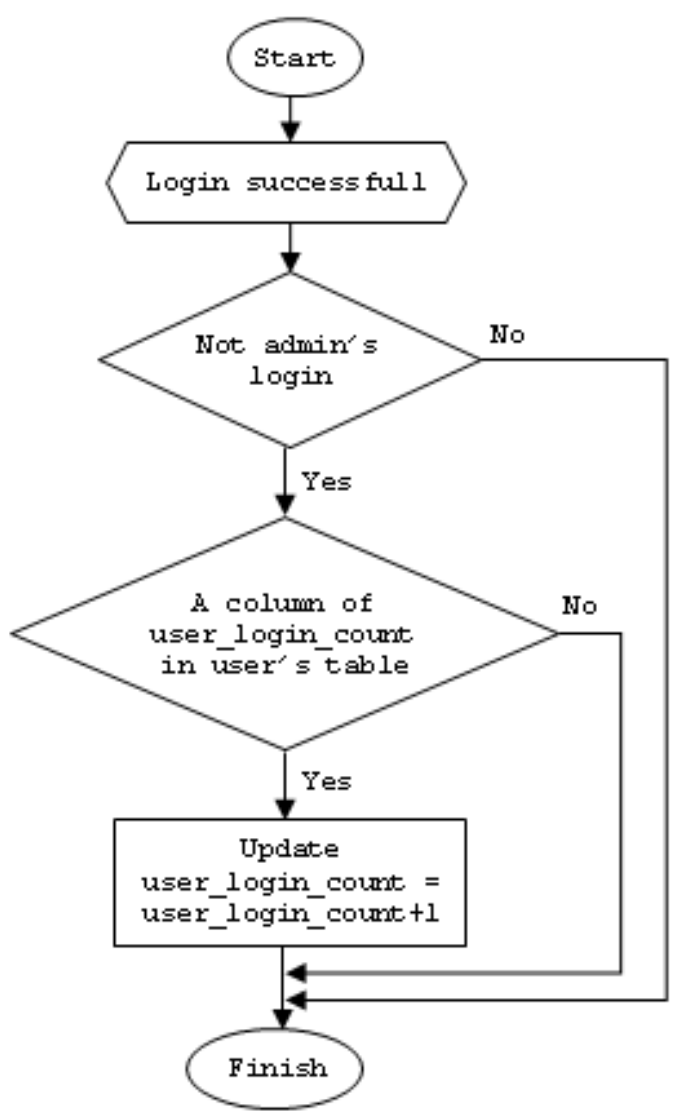

Figure 2. Flowchart user login number counter.

\section{User Registrant Viewing Submitter}

Levine (2007) revealed that there are participants who are not overactive deliver the submissions but always follow the discussion or just reading posts from friends. This statement is also supported by research conducted by Cheng, Collimore, \& Joordens (2011) showed that participation in online-course via dis- 
cussion-forum mostly only see posts without express opinion. Therefore, it is necessary to create a recorder of the participants who see the submissions. In the installation results, the new phpBB provides a function that calculates the frequency of topics seen by the user. There is no list of usernames that see the topic yet. The function to record users viewing a topic is placed in the viewtopic.php file. Previously, also added table topic_user_views. Flowchart of the function is shown in Figure 3.

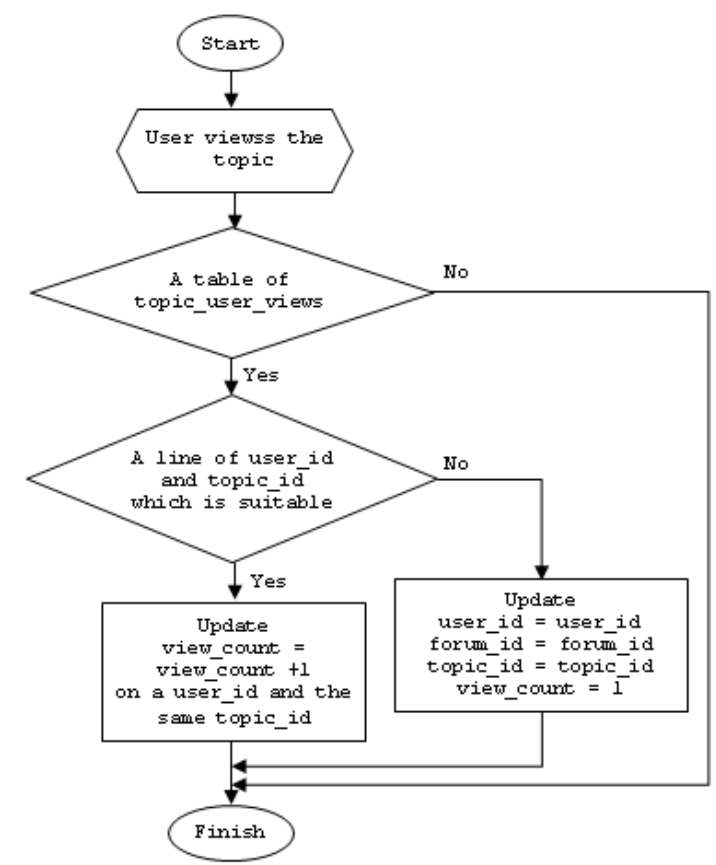

Figure 3. Flowchart of user registrant viewing submitter.

\section{Development}

Development stage is done by following steps.

\section{Product Making}

Product design results serve as a reference for product creation. Here is a description of the product manufacturing process.

\section{Theme Replacement}

From the various themes available in the community of phpBB developers, researchers use a universal theme as a substitute for the prosilver theme. This theme was developed by Inventea. The universal theme code package we can download from https:// www.phpbb.com/customise/db/style/we_universal/. Section headers are adjusted to better show the identity of physics. The result of the theme adjustment is shown in Figure 4.

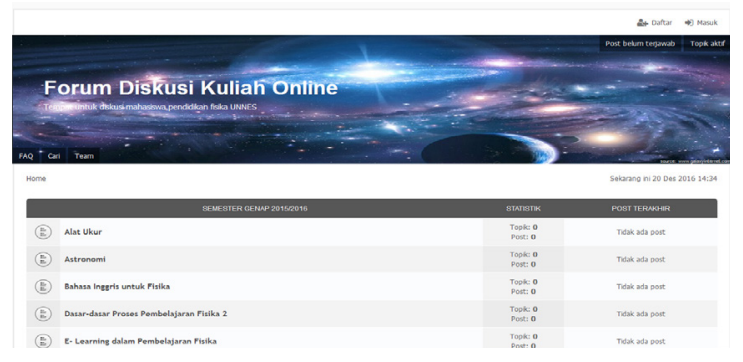

Figure 4. Display of online discussion forum.

\section{Adjustments Language}

The phpBB developer community has translated the language from the installation to various languages. From the data of the community, the results obtained https://www. phpbb.com/customise/db/translation/indonesian/ page translation into Indonesian by Sastra Manurung. However, this translation was last updated in 2011 so that there are parts that are less appropriate or not yet available for phpBB version 3.1.8. The researcher corrects and adds translations so that the entire phpBB display appears in Indonesian.

\section{BBcode for Mathematical Equations}

The phpBB extension developer Marco van Oort and sergio91pt have created an extension that can connect MathJax with phpBB. This extension code is downloaded from https:// github.com/marcovo/phpbb_mathjax. MathJax is a JavaScript program for displaying mathematical equations on the website. With MathJax integration with phpBB, a user can write the equation in the form of latex. Once sent, the latex code would appear to be a mathematical equation. The result of the addition of the latex BBcode and the example of its use is shown in Figure 5 in the red circled plane.

To provide instructions for writing formulas on submissions, a guide to writing formulas in the FAQ is prepared. To be less meet the FAQ section, complete instructions write a formula created in the form of links connected with the files on google drive.

\section{BBCode to Embed Video}

The result of adding BBCode embed video and examples of its use is shown in Figure 6.

\section{Counter of User Login Count}

Counters log the number of users created by the flowchart in Figure 2. This function will record each time a user successfully logs in to the online-course via discussion-forum. 


\section{User Registrant Viewing Submitter}

Registrars users who viewed submissions made by the flowchart in Figure 3. The Registrar of users who viewed submissions will record each user who viewed a topic that has been sent.

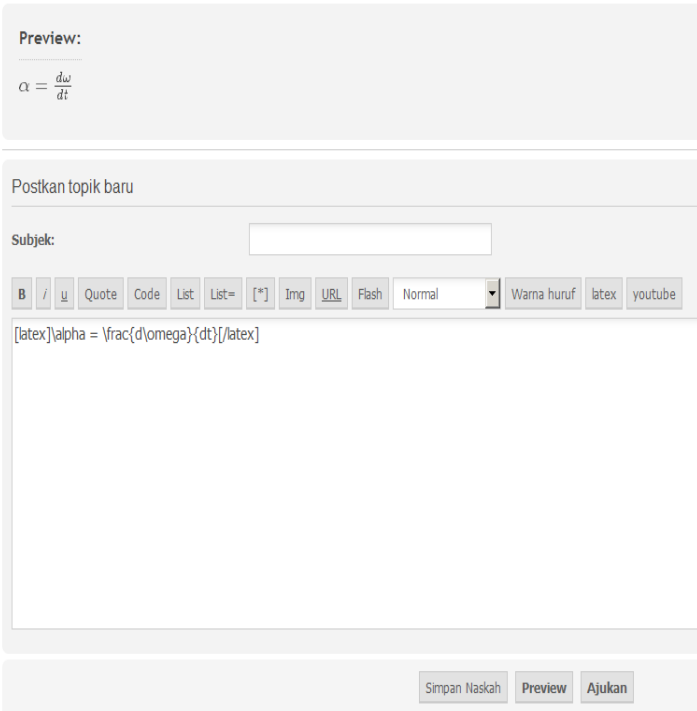

Figure 5. BBCode latex to write the mathematical equation.

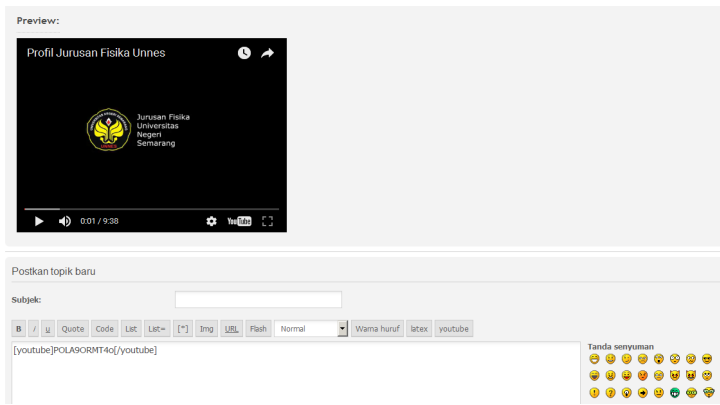

Figure 6. BBCode embed video youtube.

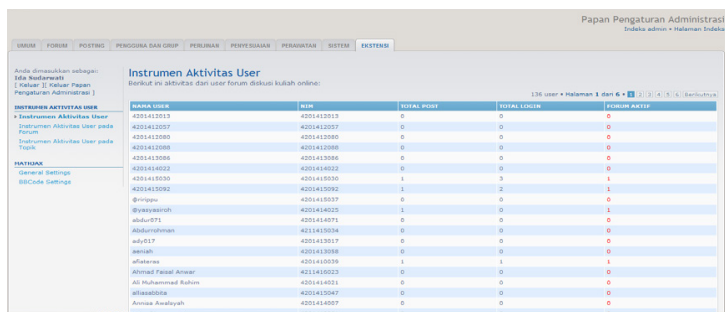

Figure 7. Instruments of user activity.

User Activity Instruments, Forum Activities, and Activities on Topics

The user activity tools, activity on the forum, and activity on the topics that have been created are shown in Figure 7. This view can only be accessed by the administrator.

Instrument user activity displays a list of user names, NIM, total posts, total logins, and an active forum. Active forums show the number of forums that users have used to submit posts. The number of active forums in the form of link that if clicked will display a list of names forum where users submit posts and the number of submissions by each user on the forum. Instrument user activity on the forum begins by displaying a selection list of available forums and browse buttons. If the user has selected the forum and pressed the view button, it will show a list containing the users who have submitted the submissions and the number of submissions from each user.

Instrument user activity on the topic begins by displaying a selection list of available forums and browse buttons. If the user has selected the forum and pressed the view button, it will show a list of topic options that have been created on the forum and the view button. If the user has selected the topic and pressed the view button, then the active user will appear on the topic either just view the topic or send the post.

The product that has been generated ensures that all parts work. The products were then uploaded to the web hosting. Online course discussion forum that has been developed can be accessed through diskusi.belajarfisika. web.id page or through a google search by keyword online-course via discussion-forum. Web servers are used using PHP version 5.4 and MySQL version 5.6.34. The product database that has been developed has 68 tables because it has been added one table.

\section{Instrument Making}

The instrument was made in this study is the assessment form, questionnaire responses of students, and student perceptions questionnaire about learning through online-course via discussion-forum. The assessment sheets and students' responses questionnaire were based on criteria from Aladwani \& Palvia (2001). The instrument used fulfills the validity of the construct.

The assessment sheet has 22 indicators divided into 3 aspects namely technical, content, and design respectively with the number of 8,6 , and 8 indicators. The assessment sheet is attached at Appendix 5. The students' responses questionnaire has 19 indicators which are also divided into 3 aspects namely technical, content and design respectively with 7,5 , and 7 indicators. Students' responses questionnaire attached in Appendix 11. Question- 
naire about students' perceptions of learning through online course discussion forum has 11 statements divided into five aspects namely ease of use, level of interactivity, convenience in studying physics, ease in learning physics, and continued use.

\section{Product Validation}

The results of the product validation conducted by validator states that online-course via discussion-forum included in the criteria developed very decent with a percentage of $84.24 \%$. These results indicate that the onlinecourse via discussion-forum has been developed ready for use.

\section{Implementation}

Online-course via discussion-forum that has been developed is used by students to discuss at the beginning of odd semester $2016 / 2017$. Users who signed up for the research process and approved as many as 136 users. The courses included in the onlinecourse via discussion-forum are the courses of Physics Education Study Program available in odd semester of 2016/2017 academic year the number of 32 subjects. The entire course is included in the online-course via discussionforum, not mostly subjects only, in order to facilitate discussions that may occur on all these subjects.

During the study, discussions took place in several subjects, they are Basic Physics 1, Computational Physics, Mathematical Physics 2 , and Mechanics 1. The number of topics and submissions in each course and the number of users are shown in Table 1. Examples of discussions that occur as in Figure 8.

Students who have been using onlinecourse via discussion-forum were given a questionnaire about students' responses and students' perceptions of learning through online-course via discussion-forum.

Evaluation

At this stage, the analysis of data ob- tained in the preceding stage is related to the feasibility study online-course via discussionforum and students' perceptions about learning through online-course via discussion-forum.

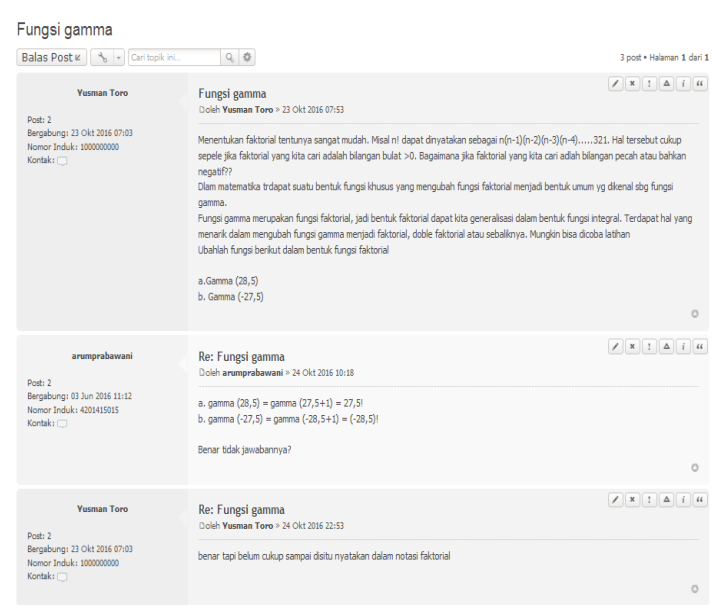

Figure 8. The Example of discussion.

The results of the data analysis of the feasibility of online-course via discussion-forum are presented in Table 2.

The technical aspects include user data security, ease of operation, availability, functionality link, the browser customization, loading speed, ease of access, and search functions. The results of due diligence on the technical aspects of online course discussion forum validator obtain the percentage of $84.17 \%$ with a very decent criteria and feedback of students earn a percentage $77.14 \%$ with a decent criteria as in Table 4.2. Online-course via discussion-forum is considered very worthy of study because it is easy to operate, always accessible, all the links work properly, it can be opened in any browser, as well as easy to access. Zhang \& Dran (2001) states that the ease of operation and the search function is an important feature of educational websites.

Aspect contents include possible use, usage instructions, developer identity, contact information, FAQs, and registration forms. As-

Table 1. Data online discussions.

\begin{tabular}{lccccc}
\hline Courses & Topic & $\begin{array}{c}\text { Number of Us- } \\
\text { ers Delivering } \\
\text { Submissions }\end{array}$ & $\begin{array}{c}\text { Number } \\
\text { of Sub- } \\
\text { missions }\end{array}$ & $\begin{array}{c}\text { Number of } \\
\text { Users View- } \\
\text { ing Topics }\end{array}$ & $\begin{array}{c}\text { Frequency } \\
\text { Topic Views }\end{array}$ \\
\hline Basic Physics 1 & 3 & 4 & 9 & 11 & 41 \\
Computational Physics & 1 & 2 & 2 & 6 & 14 \\
Mathematical Physics 2 & 3 & 4 & 6 & 5 & 27 \\
Mechanics 1 & 1 & 2 & 2 & 4 & 7 \\
Total & 8 & 12 & 19 & 26 & 89 \\
\hline
\end{tabular}


pects of the contents from online course discussion forum earn a percentage $85.56 \%$ with a very decent criteria of due diligence validator and the percentage of $79.03 \%$ with a decent criteria of students' responses. This result was obtained because the features in the onlinecourse via discussion-forum supports for the online-discussion. Completeness of a website already exist on online-course via discussionforum, such as FAQs, application forms, and instructions for use.

Aspects of the design include appearance, organization, clarity of text, blend colors, language, layout, responsive, and accuracy. The feasibility test result on the design aspect obtained the percentage of $83.33 \%$ with the eligible criteria of the validity test and the percentage of $77.92 \%$ with the eligible criteria of the students' response. College online discussion forum developed to perform well on a variety of devices used for phpBB has advantages responsive display. In addition, online-course via discussion-forum is well organized so that each topic delivered already at the appropriate courses. This agrees with the results of Wijayati's (2013) study that discussion forums should be well organized through categories that can be selected to suit the topics being discussed. Therefore, a website developed be appropriately used for online-course via discussion-forum.

The advice given by the validator on the products developed, namely that online-course via discussion-forum connected by means other notices that more frequently accessed by student. This suggestion is used as reference product revision so that notifications in online- course via discussion-forum are also delivered via email users. The revised to make users aware of the new message notification via email without having to open an online-course via discussion-forum page first.

Overall of the technical aspects, content, and design, online-course via discussion-forum developed included in the criteria are eligible with the percentage of $81.08 \%$. These results indicate that the online-course via discussionforum that has been developed ready for use.

The results of the data analysis physics education students' perception about learning through online-course via discussion-forum are presented in Table 3.

Table 3 shows that ease of use gets the highest percentage of $74.55 \%$ with good category obtained from the statement of effectiveness as supporting media lectures and ease of use. These results indicate that the onlinecourse via discussion-forum is easy to use and effective as supporting media lectures. Ease of use got a good category for the display of online-course via discussion-forum is easy to be operated by the user. Research Cheng et al. (2011) showed the same results that the online-course via discussion-forum with phpBB is easy to use and effective for lectures.

Aspects of interactivity level get percentage $68,89 \%$ with good category. Aspects of interactivity levels include participation desire, communication skills development, and increased willingness to share lecture materials. Online-course via discussion-forum become a medium for exchanging information. Students who already understand the material or can do

Table 2. The test results.

\begin{tabular}{ccccc}
\hline \multirow{2}{*}{ Aspect of Assessment } & \multicolumn{2}{c}{ Validator } & \multicolumn{2}{c}{ Students' Responses } \\
\cline { 2 - 5 } & Percentage $(\%)$ & Criteria & Percentage (\%) & Criteria \\
\hline Technical & 84.17 & Very Feasible & 77.14 & Feasible \\
Content & 85.56 & Very Feasible & 79.03 & Feasible \\
Design & 83.33 & Feasible & 77.92 & Feasible \\
Average & 84.24 & Very Feasible & 77.93 & Feasible \\
Overall & Percentage & 81.08 & Criteria & Feasible \\
\hline
\end{tabular}

Table 3. Perception of students on learning through online course discussion forum.

\begin{tabular}{ccc}
\hline Aspect of Assessment & Percentage (\%) & Criteria \\
\hline Easy to use & 74.55 & Good \\
Interactivity level & 68.89 & Good \\
Comfort in learning physics & 64.24 & Good Enough \\
Make it easy to learn physics & 72.12 & Good \\
Advanced Use & 73.64 & Good \\
Overall & 70.52 & Good \\
\hline
\end{tabular}


the questions can participate by sharing their understanding. This activity has an impact on students' communication skills. These results conformed with Shana's research (2009) which states that one of the activities that benefit from the online discussion is to interact and share ideas and lecture material.

Comfort in learning physics aspects of obtaining the percentage of $64,24 \%$ with good enough category derived from statements of learning more fun and be more likely to learn. This result was obtained because the student participation rate is still low as in Table 1 so that the user can not adjust to the use of onlinecourse via discussion-forum. This is a limitation of research, only a few students participate in the discussion. Student participation in onlinecourse via discussion-forum needs to be a concern, based on Levine's statement (2007) that encourages participants to actively participate in online discussion can be a major challenge. Cheng et al. (2011) in his research that uses an online-discussion forum on the course with voluntary participation, which do not include participation in an online discussion on the assessment format, shows that the number of students that at least convey the items contained only about $11 \%$. Conversely, research Seethamraju (2014), which includes participation in online discussion on the assessment of obtaining high levels of participation that all students participate in the discussion. From the statement above, if you want to obtain a high level of participation, it is recommended that teachers include participation in online discussion to be part of the assessment.

Aspects ease in learning physics earn a percentage $72.12 \%$ with both categories. These aspects include an increase in the understanding of the material and do the questions of physics. From some of the discussions that took place, students discussed the problems or tasks that are difficult to work independently. The discussion assist students in understanding the material and do the questions of physics. It is appropriate with Tarin statement's (2005) that the benefits of group discussion include the ability to provide more resources for solving many problems.

It should also be observed on the aspects of the use of advanced also earn a percentage is high at $73.64 \%$ with both categories derived from an expression of interest that most of the course utilizing online-course via discussion-forum and will participate actively if the online-course via discussion-forum is used more for support lectures. This result is an opportunity for teachers to take advantage of online-course via discussion-forum. Shana's study (2009) showed the same results that the students would be happy to participate in the discussion forum based web in the future.

From the aspect of ease of use, the level of interactivity, convenience in studying physics, facilitate the study of physics, and the use of advanced, it is obtained by percentage of $70.52 \%$ and are included in both criteria. These results indicate that the student has a good perception related learning through online-course via discussion-forum. These results are in line with Wu \& Hiltz researchs' (2004) stated that students have a good perception of learning through online discussion .

\section{CONCLUSION}

From this research, it has developed an online-course via discussion-forum with ADDIE development model. The development process includes the stage of problem analysis, design, development, implementation, and evaluation. The result of this development study is an online-course via discussion-forum that can be used by students to discuss physics courses. Online-course discussion forum that meet the criteria are eligible to be developed based on the assessment validator and student feedback. Physical education students' perceptions of learning through online-course via discussion-forum are included in both criteria.

Advice given to further research that it is neccessary to socialize on the entire students of physics education so that the participation rate is high, the use of online-course via discussion-forum should involve the lecturer of the course so that the contents of the discussion can be ascertained the truth, the use of online course discussion forum for discussion between students from different universities to facilitate a wider exchange of ideas, as well as further research on the use of online-course via discussion-forum intensely on certain subjects.

\section{REFERENCES}

Aladwani, A.M., \& Palvia, P.C. (2001). Developing and Validating an Instrument for Measuring User-Perceived Web Quality. Information \& Management, 39 (6): 467-476.

Arkün, S., \& Akkoyunlu, B. (2008). A Study on the Development Process of a Multimedia learning Environment According to the ADDIE Model and Students' Opinions of The Mul- 
timedia Learning Environment. Interactive Educational Multimedia, 17: 1-19.

Asosiasi Penyedia Jasa Internet Indonesia (APJII). (2015). Profil Pengguna Internet Indonesia 2014. Online. Retrieved from https://beta. apjii.or.id/downfile/file/PROFILPENGGUNAINTERNETINDONESIA2014.pdf

Baharuddin \& Wahyuni, E.N. (2008). Teori Belajar dan Pembelajaran. Yogyakarta: Ar-Ruzz Media

Cheng, C.K., Pare, D.E., Collimore, L.M., \& Joordens, S.. (2011). Assesing the effectiveness of a voluntary online discussion forum on improving students' course performance. Computer \& Education, 56: 253-261.

Direktorat Pembinaan SMA. (2010). Juknis Penyusunan Perangkat Penilaian Afektif SMA. Online. Retrieved from regulasi.sman1jember. sch.id/index.php?dir=Peraturan+Pemerintah $+26 \%+$ Menteri $\% 2$ FPetunjuk+Teknis+dan+P edoman $\% 2 \mathrm{~F}$

Hasibuan, J.J., \& Moedjiono. (2006). Proses Belajar Mengajar. Bandung: Remaja Rosdakarya.

Levine, S.J. 2007. The Online Discussion Board. New Directions for Adult and Continuing Education, 113: 67-74.

Mazzolini, M. (2002). The Use of Online Discussion Forum as a Learning and Teaching Tool in Astronomy. Publication of the Astronomical Society of Australia, 19: 448-454.

Meyer, K.A. (2003). Face-to-Face Versus Threaded Discussion: The Role of Time and HigherOrder Thinking. Journal of Asynchronous Learning Networks, 8 (2): 55-65.

Schunk, D. H. (2012). Teori-Teori Pembelajaran: Perspektif Pendidikan (6 $6^{\text {th }}$ ed.). Translated by Hamidah, E. \& R. Fajar. Yogyakarta: Pustaka Pelajar. Seethamraju, R. (2014). Effectiveness of Using Online Discussion Forum for
Case Study Analisys. Education Research International, 2014: 1-10. Retrieved from http://downloads.hindawi.com/journals/ edri/2014/589860.pdf

Shana, Z. (2009). Learning with Technology: Using Discussion Forums to Augment a TraditionalStyle Class. Educational Technology \& Society, 12 (3): 214-228. Retrieved from http:// www.ifets.info/journals/12_3/19.pdf

Sudijono, A. (2003). Pengantar Statistik Pendidikan. Jakarta: Raja Grafindo Persada.

Sugiyono. (2010). Statistika untuk Penelitian. Bandung: Alfabeta.

Sugiyono. (2013). Metode Penelitian Pendidikan (Pendekatan Kuantitatif, Kualitatif, dan R\&D). Bandung: Alfabeta.

Tarigan, H.G. (2005). Berbicara sebagai Suatu Keterampilan Berbahasa. Bandung: Angkasa.

Thompson, H. (2005). Asynchronous Computer Mediated Communication: Pedagogical Reflections. Journal of Advanced Technology on Education, 2 (2): 225-228. Retrieved from http://www1.aucegypt.edu/faculty/thompson/ herbtea/articles/ate.htm

Wijayati, K. (2013). Perancangan dan Pembuatan Forum Diskusi Berbasis Web untuk STMIK Amikom Yogyakarta. Naskah Publikasi. Sekolah Tinggi Manajemen Informatika dan Komputer Amikom Yogyakarta.

Wu, D., \& Hiltz, S.R., (2004). Predicting Learning from Asynchronous Online Discussions. Journal of Asynchronous Learning Network. 8(2), 139-152.

Zhang, P., \& Dran, G. (2001). Expectations and Rankings of Website Quality Features: Results of Two Studies on User Perceptions. Proceedings of the 34th Hawaii International Conference on System Sciences 2001. Hawaii: Wailea. 